\title{
Learning Methods of Islamic Religious Education Teachers on Students with Developmental Impairments
}

\author{
Darmawati Darmawati ${ }^{1 *}$ Sagaf S. Pettalongi ${ }^{2}$, Mohammad Idhan ${ }^{3}$ \\ ${ }^{1}$ Islamic Education Department, Postgraduate, Institut Agama Islam Negeri Palu, Indonesia \\ ${ }^{2}$ Islamic Education Department, Postgraduate, Institut Agama Islam Negeri Palu, Indonesia \\ ${ }^{3}$ Islamic Education Department, Postgraduate, Institut Agama Islam Negeri Palu, Indonesia
}

\begin{abstract}
ABSTRAK
This study examines the learning methods of Islamic religious education in ABCD Muhammadiyah special schools Palu. The method used is a qualitative method with data collection techniques through observation, in-depth interviews, and the study of various written documents. The results of research studies on Islamic education in special schools mentally disabled ABCD Muhammadiyah shows that learning in extraordinary schools is done by using examples through direct demonstration to students. In the learning process the teacher uses a more friendly humanistic approach so that students are eager to follow the learning process. Every day the teachers give various topics of Islamic religious education learning starting in the morning until after hours of study through various demonstration activities. Besides that learning is also done through demonstrations that are carried out together and repeatedly so that students easily practice it.
\end{abstract}

ARTICLE

INFORMATION 


\section{Introduction}

Knowledge can be reached well through education and learning activities. Education in Islam is one way to develop the nature and potential that is entrusted by God, and is a conscious and systematic effort to develop and prepare fully human beings to become God's perfect beings (insan kamil). With education it is hoped that humans can overcome the problems and challenges of life they face, survive in every time, and place. Therefore, education is seen as one aspect that has a central role in shaping the younger generation so that it has a major personality. Education is not only needed by normal children, but education is also needed by children with special needs such as children with intellectual disabilities. ${ }^{1}$

The mandate of the right to education for people with disabilities is stipulated in Law No. 20 of 2003 concerning the National Education System eleventh section on Special Education and Special Service Education Article 32 paragraph 1 which states that:

Special education is education for students who have difficulty in participating in the learning process because of physical,

\footnotetext{
${ }^{1}$ Muchafid Anshori, Pendidikan Agama Islam Adaptif untuk Anak Berkebutuhan Khusus (Cet. I; Jakarta: Pustikom, 2014), 24.
}

emotional, mental, social, and / or potential disabilities and special talents. $^{2}$

Education is a basic right that must be fulfilled regardless of the background and physical condition of the child concerned, children with disabilities are entitled to the same opportunities as other children (normal children) in education. Every child cannot expect to be born with a disability or have difficulty in reading and writing so they must get more attention from the government, school, parents, the community, and the environment. In dealing with such realities of life, children with special needs need access to and educational facilities that enable them to absorb and understand the subject matter when entering the world of education. Education for children with special needs must be planned with integrated programs, learning systems, and curricula that are appropriate to the abilities and intelligence of children in receiving subject matter. The goal is that the children are able to develop knowledge, attitudes and skills as individuals and community members so that they are able to live independently and interact with the surrounding social environment.

The task of teachers as carrying out the mandate of education is indeed heavy,

\footnotetext{
${ }^{2}$ Undang-Undang Republik Indonesia Nomor 20 Tahun 2003, Sistem Pendidikan Nasional.usu.ac.id/public/content/files/sisdiknas.pdf (Akses : Jumat, 17 April 2015).
} 
they have received the mandate from parents to form a better student and virtuous and noble personality. Besides the teacher becomes the second parent for students, therefore the teacher guides him so that he becomes a child who changes in everything and is rich in knowledge that is not obtained while at home. Meanwhile, the existence of children with special needs such as mental retardation children require assistance accompanied by special patience. This is because the condition of mentally retarded children is different from other normal children who are able to quickly grasp and understand lessons taught by teachers, such as in religious learning, or inculcation of Islamic religious education values exemplified by the teacher. Children with intellectual disabilities require a special approach and require cooperation between parents and teachers so that the inculcation of Islamic religious values towards children with intellectual disabilities can succeed optimally.

The importance of Islamic religious education is based on human needs in controlling lust, and being a creature that is always religious. In the process of learning Islamic religious education, actualization of religious values in daily life is needed. In this case teaching and learning activities with the contents of religious values have a very important role. One of the teachings of
Islam teaches that people are educated so that they are able to recognize and realize their goals in life as outlined, namely worshiping Allah SWT.

The application of Islamic values is actually an important aspect to achieve the degree of pious people created solely to worship Allah SWT. But in striving for the values of Islamic religious education can not be separated with the teachings of Islam such as learning the Qur'an, aqeedah, worship, covering discipline, honestly, learning prayer, reading and writing al-Qur'an, ablution, required guidance of teachers and parents. Because in the learning process of mentally disabled children are not like other children they need full motivation and affection. Learning for mentally retarded children depends on the level of the mental retardation group itself.

One of the tasks of the school is to provide learning to students. They must acquire skills and knowledge from the school, while developing their personalities. Giving skills and knowledge to students which is the teaching process (teaching and learning process) is carried out by the teacher in the school by using certain methods.

In theory, teaching in special schools is very difficult, especially for people with intellectual disabilities. But if the teacher chooses the right method in applying Islamic 
Religious Education learning in special schools, then of course it will be able to achieve satisfying results. Such methods are intended as a method of learning in schools. Humans always try to find work efficiencies by choosing and using a method that is considered the best to achieve its goals. Likewise, in the field of learning in schools. Educators (teachers) always try to choose the most precise learning method, which is seen as more effective than other methods so that the skills and knowledge provided by the teacher truly belong to the students.

ABCD Muhammadiyah special school Palu is one of the institutions that provide educational services for children with disabilities ranging from deaf children, mentally disabled children and children with autism, in which there are teaching and learning processes. In the teaching and learning process requires an educational component that serves to achieve educational goals, while one component of education is the right learning method. The method is an important factor in the success of the implementation of learning, especially Islamic education and even determines the success or failure of a teaching and learning process in ABCD Muhammadiyah special school Palu. This motivates researchers to further examine how the efforts made by Islamic Religious Education Teachers to achieve an effective learning for mentally disabled students especially in learning Islamic religious education.

\section{Literature Review}

\subsection{Previous study}

There have been many studies conducted related to the problem of education of children with special needs. However, there are still a small number associated with teaching methods of Islamic education teachers compared to teacher who teaches mentally disabled children in learning methods in general. Existing research includes:

Tuti Rochanah in her thesis entitled Problematics of the Islamic Religious Education Learning Process in SDLB-B Deaf Students in Marsudi Putra I Special School Bantul Jogjakarta, the results of her research stated that the problems encountered in Islamic Religious Education learning included a lack of teacher competency in which Islamic Religious Education subject teachers were not graduates from SGPLB -B (deaf children's education), students' disability, lack of planning in learning, several classes in one room, the use of less effective learning time allocations, and less optimal use of media. ${ }^{3}$ The strength of this thesis is

${ }^{3}$ Tuti Rochanah, Problematika Proses Pembelajaran PAI pada Peserta didik Tunarungu SDLB-B di SLB Marsudi Putra I Bantul 
describing the problematic of teachers of religious subjects in dealing with the situation of deaf students who have various limitations, because such conditions are often found in almost all special schools or inclusive schools that deal with students with disabilities. However, in this study is limited to the description of problems that are general in nature, only describe the state of the school, not specifically mentioning how the efforts of teachers of Islamic Religious Education subjects in dealing with problems of deaf students in the implementation of Islamic Religious Education learning.

Next Muhammad Khodik in his thesis entitled Islamic Religious Learning Strategies for Students of the Deaf Students of SLPL at Yapenas Condong Catur Depok Sleman Yogyakarta implies that the learning strategies used in Islamic Religious Education learning for deaf students are lectures, example, questioning, assignment, and training. The approach used is an individual, group, and habituation approach. In supporting the implementation of strategies well for deaf students, the teacher uses the language approach with the reflective maternal method, which is a learning method that contains conversations from heart to heart, linguistic conversations,

Jogjakartahttp://library.uinsuka.ac.id/, (diakses 24 Maret 2015). and accustoms students to listening, speaking, reading and writing according to their ability students by fostered by the teacher. ${ }^{4}$

Indrawati Amien in her thesis entitled Learning Strategies of Islamic Religious Education in Mental Development of Students in State National Level Special School Malang Guides concluded that the mental development process of students, an Islamic religion teacher in delivering material must have the right strategy because with the strategy the coaching process mental learners can walk properly and optimally. That way students can understand about all religious material. Human soul or mental needs to be nurtured in order to instill Islamic religious values in him. The purpose of mental development through Islamic religious education is to try to foster morals, develop reason and conduct behavior in the personalities of students so that they have personalities that are in accordance with the teachings of Islamic religion. Moral education can be a benchmark for the mental development of a child. $^{5}$

Zaenal Alimin in his dissertation

\footnotetext{
${ }^{4}$ Muhammad Khodik "Strategi Pembelajaran Pendidikan Agama Islam Bagi Peserta Didik SMPLB Tunarungu di SLB Yapenas Condong Catur Depok Sleman Yogyakarta "http://library.uinsuka.ac.id/ (diakses 24 Maret 2015).

${ }^{5}$ Indrawati Amien "Strategi Pembelajaran Pendidikan Agama Islam dalam Pembinaan Mental Peserta didik di SLB Negeri Pembina Tingkat Nasional Malang” http/:uin-malang.ac.id/- (diakses 05 April 2015).
} 
entitled The Counseling Based Learning Model for Children with Developmental Disabilities states that learning integrated with counseling for mentally retarded children can help the optimal development of potential learners especially those with disabilities. ${ }^{6}$ This study provides a positive idea of mentally disabled children's learning patterns. Through the case of mental retardation children who have problems with intelligence and mental, gradually intellectual retardation children change their independence. Each learning must contain an element of counseling. Starting from this study the emergence of concepts such as adaptive physical education, adaptive skills, fostering adaptive behavior, adaptive arts, and so forth. But this dissertation does not mention how about Islamic education? Can Islamic education be taught adaptively? Surely it must be. Hetergonitias, differences in abilities, characteristics, unique needs of each individual that drives Islamic Religious Education should be taught adaptively.

There is quite a lot of general research on learning methods for mentally disabled chil, but many studies of learning methods related to Islamic education for mentally retarded students researchers have not found any. On the basis of the importance of Islamic Religious Educationlearning towards retarded students, this research needs to be done.

\subsection{Mentally disabled Learning Methods}

The learning process is now better known as learning as an activity to try to encourage, guide someone to get, change, or develop skills, attitudes, ideals, appreciation, and knowledge. In this sense, educators are required to bring about changes in behavior or a direct tendency to change the behavior of their students. So, educators are required to be creative and innovate in everything, including creating creative learning methods.

The word method comes from Greek. Etymologically, the word method comes from two syllables, namely metha means through and hodos means way. So, the method is the steps taken by an educator to help students realize certain goals. In Arabic, the word method is known as Tariqah which means strategic steps that must be prepared to do a job. When connected with education, then these steps must be realized in the educational process within the framework of the formation of the learner's personality. Thus it can be understood that the method is a way or path

\footnotetext{
${ }^{6}$ Zaenal Alimin "Model Pembelajaran Berbasis Konseling pada Anak Tunagrahita"http://file.upi.edu/Direktori/pdf (diakses 05 april 2015).
} 
that must be traversed to achieve a goal. ${ }^{7}$

Learning is an activity carried out by the teacher programmed in instructional design that creates a process of interaction between fellow students, teachers with students and with learning resources. Learning aims to create continuous change in the behavior and thinking of students in a learning environment.

The learning process is inseparable from teaching and learning activities. Learning is a process that is marked by a change in a person. One sign that someone has learned something is a change in behavior in him. Changes in behavior involve changes in the nature of knowledge (cognitive), skills (psychomotor) and those concerning values and attitudes (affective). Learning not only includes subjects, but also mastery, habits, perceptions, fun, competence, social adjustment, various skills, and ideals.

Learning is essentially a process of interaction between students and their environment, so that changes in behavior occur for the better. During the learning process, the most important task of the teacher is to condition the learning environment in order to support the behavior change for students. Learning is a two-way communication process, teaching is carried

\footnotetext{
${ }^{7}$ Moh. Haitama Salim \& Syamsul Kurniawan, Studi Ilmu Pendidikan Islam (Jogjakarta; Ar-Ruzz Media, 2012), 211-210
}

out by the teacher as an educator, while learning is carried out by students. Based on learning theory there are five terms of learning including the following:

a. Learning is an effort to convey knowledge to students in schools.

b. Learning is passing down culture to the younger generation through school institutions.

c. Learning is an effort to organize the environment to create learning conditions for students.

d. Learning is an effort to prepare students to become good citizens.

Learning is a process of helping students deal with people's daily lives. ${ }^{8}$

According to Gagne as stated by Nazarudin learning can be interpreted as a set of external events designed to support an internal learning process. According to Nazarudin learning is an event or situation that is deliberately designed in order to help and facilitate the learning process in the hope of building students' creativity. So, learning is a change from an event or situation that is designed in such a way with the aim of providing assistance or convenience in the teaching and learning process so that it can achieve the learning objectives. ${ }^{9}$

Based on the description above it can

\footnotetext{
${ }^{8}$ Oemar Hamalik, Belajar dan KesulitanKesulitan Belajar, edisi ke-3 (Bandung: Tarsito, 1990), 23

${ }^{9}$ Muhammad Ali, Guru dalam Proses Belajar Mengajar, (Cet. 13; Bandung: Algensindo, 1910), 2.
} 
be concluded that the learning method can be interpreted in a unique way or pattern in utilizing various basic principles of education as well as various techniques and other related resources so that the learning process occurs in the self-learner.

The learning method is a presentation technique mastered by a teacher to present subject matter to students in class both individually or in groups so that the subject matter can be absorbed, understood and utilized by students well. Thus the method in a series of learning systems plays a very important role, because the success of learning is very dependent on the way the teacher uses the learning method.

\section{Characteristics of Good Learning} Methods

Many methods can be chosen by a teacher in teaching and learning activities. Therefore every teacher who will teach is expected to choose a good method. Because whether or not a method that will be used in the teaching and learning process lies in the accuracy of choosing a method in accordance with the demands of the teaching and learning process.

The characteristics of a good method for teaching and learning are as follows:

a. Be flexible and have the power in accordance with the character of students and material. b. Be functional in uniting theory with practice and leading students to practical abilities.

c. Does not reduce material, even on the contrary develop material.

d. Give flexibility to students to express their opinions.

e. Able to place the teacher in the right position, respectable in the whole learning process. $^{10}$

The use of a learning method must pay attention to the following:

a. The method used can arouse students' motivation, interest or enthusiasm for learning.

b. The method used can guarantee the development of students' personality activities.

c. The method used can provide opportunities for students to realize their work.

d. The method used can stimulate students' desire to learn more, explore and innovate.

e. The method used can educate students in their own learning techniques and how to acquire knowledge through personal effort.

f. The method used can negate the presentation of a verbal nature and replace it with real or purposeful

10PupuhFathurrohman\&M.SobrySutikno,StrategiBel ajarMengajarmelaluiPenanamanKonsepUmumdanIslami( Bandung:RafikaAditama,2007),56. 
experiences or situations.

g. The method used can instill and develop the main values and attitudes expected in the habit of working well in daily life. ${ }^{11}$

Based on the description above, it can be concluded that a method that will be used in the teaching and learning process can be said effective if the method can develop the potential of students.

2. Principles for Determining Learning Methods

The process of teachers' teaching and learning in determining the method should not be used randomly, in determining the method the teacher must go through selection in accordance with the formulation of learning objectives. Whatever method is chosen in teaching and learning activities should pay attention to the accuracy (effectiveness) of the learning methods used in the teaching and learning process.

The principles of determining the method in the teaching and learning process are as follows:

a. The principle of motivation and learning objectives. Motivation has a very powerful power in the teaching and learning process. Learning without motivation is like a body without a soul. Likewise, teaching and learning processes that do not have unclear goals will not be

\footnotetext{
${ }^{11} \mathrm{Abu}$ Ahmadi dan JokoTriPrastya,53.
}

directed.

b. The principle of individual morals and differences. All developments in children have different tempos, therefore every teacher should pay attention to the time and rhythm of child development, motives, intelligence and emotion of speed of capturing lessons, as well as nature and environmental factors.

c. The principle of providing opportunities and practical experience. Learning by paying attention to maximum opportunities for student participation and direct experience will have more meaning than verbal learning.

d. Integration of understanding and experience. The integration of understanding and experience requires a learning process that is able to apply real experience in a teaching and learning process.

e. Functional principle. Learning is a process of life experience that is beneficial for the next life. Every learning seems to be inseparable from the value of benefits, even though it can be in the form of theoretical or practical benefits for daily life.

f. The principle of rejoicing. Learning is a process that continues without stopping, of course as needs and demands continue 
to grow. Associated with the importance of continuous learning, the teaching method should not give the impression of burdensome, so that the awareness of children to learn quickly ends. ${ }^{12}$

By paying attention to the principles of determining the learning method above, it is expected that the teaching and learning process can be more effective and efficient and can optimize the achievement of the objectives to be achieved, because by paying attention to these principles a teacher can consider which method is suitable for use in the teaching and learning process.

3. Types of learning methods

Some learning methods that are generally known include:

a. Lecture method, provides understanding and description of a problem.

b. Methods of discussion, solving problems with various responses.

c. Experimental method, trying to find out the process of the occurrence of a problem.

d. Demonstration method, using props to clarify a problem.

e. Assignment method, by giving certain tasks freely and responsibly.

f. The sociodrama method, shows the behavior of life.

g. The drill method, train measures the absorption of subjects.

${ }^{12}$ Ibid.,56-59. h. Question and answer method, solving problems with feedback.

i. Project methods, solving problems with steps scientifically, logically, and systematically. ${ }^{13}$

Based on the various learning methods described above, it can be emphasized that the learning method is the method used by teachers in organizing classrooms in general or in presenting learning materials in particular. This learning method also requires students to practice conducting systematic observations, taking notes, and making written reports using various learning media facilities available.

\subsection{Characteristics of Mentally Disabled}

\section{Children}

Mental retardation is a condition in which the development of intelligence experiences obstacles so it does not reach the optimal development stage. There are some common characteristics of mental retardation that we can know of, namely:

\section{1) Limitations of Intelligence}

Intelligence is a complex function that can be interpreted as the ability to learn information and skills to adjust to the problems and situations of new life, learn from past experiences, think abstractly, creatively, be able to judge critically, avoid

${ }^{13}$ Zakiah Darajat, dkk., Metodologi Pengajaran Agama Islam (Cet. 2; Jakarta; Bumi Aksara, 2001), 289312. 
mistakes, overcoming difficulties, and the ability to plan for the future. Children with intellectual disabilities have deficiencies in all of those things. The learning capacity of mentally retarded children, especially those of an abstract nature such as learning to count, write and read is also limited. Learning ability tends to be without understanding or tendency to learn by parrot.

Delays in cognitive development in mentally retarded children become a major problem for mentally retarded children when pursuing their developmental tasks. Some barriers that appear in mentally retarded children in terms of cognitive and at the same time become its characteristics, namely:

a) Tend to have the ability to think concretely and have difficulty thinking

b) Having difficulty in concentration

c) Limited socialization abilities

d) Unable to save difficult instructions.

e) Lack of ability to analyze and assess the events encountered.

f) In mentally retarded students, the highest achievement in the fields of reading, writing, counting is no more than a normal child of grade III-IV Elementary School. ${ }^{14}$

2) Social Limitations

\footnotetext{
${ }^{14} \mathrm{M}$. Efendi, PengantarPsikopedagogikAnakBerkelainan (Jakarta: PTBumi Aksara, 2006), 98.
}

Besides having limited intelligence, mentally retarded children also have difficulties in taking care of themselves in the community, they really need help from others. Children with intellectual disabilities tend to be friends with younger children, dependence on parents is very large, unable to shoulder social responsibility wisely, so they must always be guided and supervised. They are also easily influenced and tend to do things without thinking about the consequences. ${ }^{15}$

As an individual and social creature, a mentally retarded child has a desire to fulfill all needs as befits a normal child, but the efforts of a mentally retarded child often experience significant failures and obstacles. As a result, mental retardation children are easily frustrated, from feelings of frustration in turn will appear deviant behavior as a reaction from self-defense mechanisms and as a form of wrong social adjustment. The form of adjustment that is wrong in retarded children, namely: excessive compensation, displacement, regression, delinquent, destruction, and aggression. ${ }^{16}$

3) Limitations of Other Mental Functions

The mentally retarded child needs more time to complete the reaction to the situation he just knows. They show their best reaction when they follow routine things and

\footnotetext{
${ }^{15}$ Sutjihati, 105.

${ }^{16}$ M. Efendi, Efendi, 103.
} 
they experience them consistently from day to day. The mentally retarded child cannot deal with any activity or task for a long time. Children with intellectual disabilities have limitations in language acquisition. They are not experiencing articulation damage, but the processing center (vocabulary) is not functioning as it should. For that reason they need concrete words that are often heard. In addition, differences and similarities must be shown repeatedly. Simple exercises such as teaching big and small concepts, hard and weak, first, second, and last, need to use a concrete approach.

In addition, mentally retarded children are less able to consider something, distinguish between good and bad, and distinguish right from wrong. This is all because of limited ability so that the mentally retarded child cannot first imagine the consequences of his actions. ${ }^{17}$

The characteristics or physical characteristics (appearance) of mentally retarded children, namely:

a) Down Syndrome (Mongoloid). This mental retardation child is called so because it has a Mongolian-like face with slanted eyes, thick tongue protrudes out, small ears, rough skin, poor arrangement of teeth.

b) Cretin (Midget). This child shows characteristics, such as short and fat

\footnotetext{
${ }^{17}$ Ibid, 106.
}

body, short and crooked legs and hands, dry skin, thick and wrinkled, dry hair, tongue and lips, eyelids, thick palms and hands, late tooth growth.

c) Hydrocephal. This child shows the characteristics of a large head, small features, imperfect vision and hearing, eyes sometimes squinting.

d) Microcephaly. This child has a small head size.

e) Macrocephal. This child has a large head size than normal size. ${ }^{18}$

4) Factors That Cause Developmental Disabilities

\section{Methodology}

This study uses a qualitative approach with the object of research is a special school in Palu. In this study, the writer took one of the special schools that exist, namely ABCS Muhammadiyah special school Palu to be used as a case in this study.

Bogdan \& Taylor defines qualitative methods as research procedures that use descriptive data in the form of written / oral words from people and observed behavior. ${ }^{19}$ Indications of this research model that distinguishes it from other types of research include: the existence of a natural background, humans as a tool or instrument,

\footnotetext{
${ }^{18}$ Muhammad Amin, Ortopedagogik Anak Tunagrahita, (Jakarta; Proyek Pembinaan dan Peningkatan Mutu Tenaga Kependidikan, 1996), 58.

${ }^{19}$ Lexy. J.Moleong, MetodologiPenelitianKualitatif, (Bandung:PT.Remaja Rosdakarya,2013), 3.
} 
qualitative methods, inductive data analysis, grounded theory, descriptive, prioritizing processes rather than results, there is a limit that is determined by the focus, the existence of specific criteria for the validity of the data, the design is temporary, the results of the study are negotiated and agreed upon. ${ }^{20}$ This study will observe the teaching methods of Islamic religious education teachers on mentally disabled students who aim to describe systematically about the facts found in the field are verbal, sentence, phenomena and not in the form of numbers.

Data were collected using observation techniques, in-depth interviews and studies from shared written documents. While the data analysis is done using reduction and verification techniques with various data sources. The data that has been reduced is then analyzed by claiming to the theoretical concepts used in this study.

\section{Results and Discussion}

4.1 Characteristics of Islamic religious education learning

The characteristics of Islamic learning in ABCD Muhammadiyah Speacial School Palu at the elementary school level are almost the same as regular schools, the curriculum is relatively the same as the curriculum at public schools, limited only to the amount of material. The curriculum used

20ibid, 8-11 at ABCD Muhammadiyah Special School Palu at the elementary school level is School-Based Curriculum. The curriculum of the National Education Standards Agency for students with special needs is not in accordance with the reality of the student's situation. The curriculum is very difficult to be implemented by students with special needs, because the curriculum provided is like a curriculum for normal students. The curriculum required by students should be adjusted to the ability of students.

The curriculum needed by mentally retarded students in particular, must include how to communicate, how to socialize, movement skills, self-maturity and social responsibility. The steps of ABCD Muhammadiyah Special School Palu at the elementary school level in lowering Basic Competence from National Education Standards Agency are guided by the special principles of learning for mentally disabled students. The principle is to simplify the material if there is material that is difficult for students to accept. School-Based curriculum is a curriculum that is developed in accordance with the education unit, school / regional potential, school / regional characteristics, local community's social culture, and student characteristics. Based on Government Regulation (PP) No. 19 of 2005 and guidelines for the preparation of the curriculum created by National Education 
Standards Agency, each education unit is expected to develop a curriculum that is implemented in their respective education units. Education units that are not ready to develop curriculum, can use the curriculum model developed by National Education Standards Agency.

Based on the above, the material taken at ABCD Muhammadiyah Special School Palu at Elementary School level is determined solely by the school with a curriculum made. The material provided is simple material that is discussed daily with Islamic customs (interview on 23 October 2015).

After conducting research at $\mathrm{ABCD}$ Muhammadiyah Special School Palu at the elementary school level, the researcher learned the characteristics of learning, especially Islamic Religious Education. Before describing the characteristics of learning the researcher gives an explicit description of the character of students in the classroom. Learning activities in ABCD Muhammadiyah Special School Palu at the elementary school level in terms of classrooms are divided into 6 (six) classes, each class is inhabited by students with varied types of disabilities but is more dominant in mild and moderate retarded learners. In each class the number of students is no more than fifteen. Most consist of mild mental retardation, where they are able to read and write. Then downsyndrom, they are also able to read but only per letter, and are slow in writing. The form of organizing the learning is made into one class because the number of mild retardation and downsyndrom are not many in each generation. With the number of students that are not large, and a variety of character teachers must be very clever in conditioning the classroom so that learning runs smoothly. By using the method of observation, interviews, and documentation, researchers can describe the research data, as follows:

Based on the observations of the researcher while in the location and interacting with mentally disabled students, it is known that the characteristics of Islamic Religious Education learning appear in daily learning activities.

When starting learning activities the teacher invites students to pray andread the Surah Al-Fatihah. Likewise in the end of the learning, students are invited to pray and read short surah. Then students mimic what is read by the teacher. In the description above it has been alluded with regard the difference in character of the students, it is not surprising that there are often quarrels between students when learning takes place. If that happens the action taken by the teacher is to break it up and ask to shake hands to apologize to each other. From this, 
learning approaches become urgency in the success of educating students' affective as well as cognitive and psychomotor, on learning especially Islamic Religious Education. Following are the results of observations showing teaching and learning activities in class $\mathrm{C} \mathrm{II,} \mathrm{C1.}$

On the sidelines explaining the teacher provides motivation, such as "if you do not pray then you will sin, and go to hell". For students who can only copy and thicken the writings the teacher provides pictures of the prayer, then underneath is given the writing prayer. With these broken points students will then bold the writing. Likewise with those who have difficulty reading, the teacher starts then the students continue. All that is done repeatedly.

Researcher's observations above found many approaches taken by the teacher, ranging from habituation, experience, emotional, and exemplary. The observation of the researcher is the same as what the teacher revealed when asked for information about the characteristics of Islamic Religious Education learning. The following is a statement from him:

In this class a variety of students were told to write and they could. The other two are also capable but must be given a response first, while this one is only able to bold the writing. For this reason, it is not possible to teach them here like in normal schools, they must be patient with them one by one, and the most important thing is they must be accustomed to it.
The results of the interview above illustrate the characteristics of Islamic Religious Education learning, namely using several approaches to the learning activities of Islamic Religious Education on mentally disabled students. Like accustom them to continue to practice writing, praying. And the most important thing is to pay attention to each character of the students.

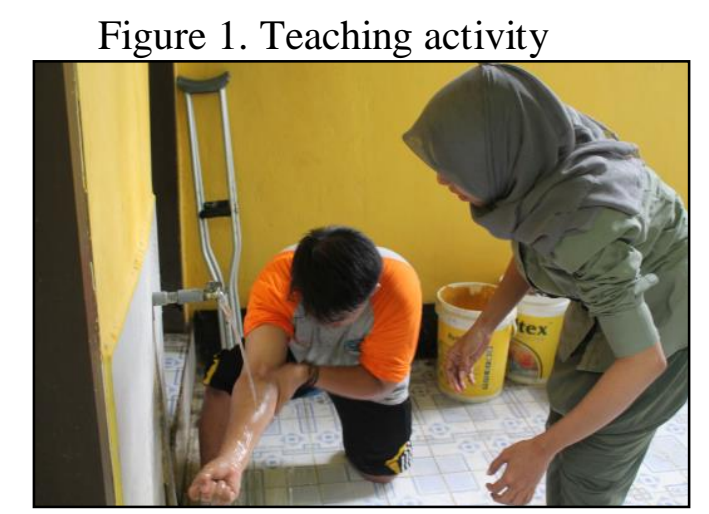

Figure 2. A teacher is teaching ablution

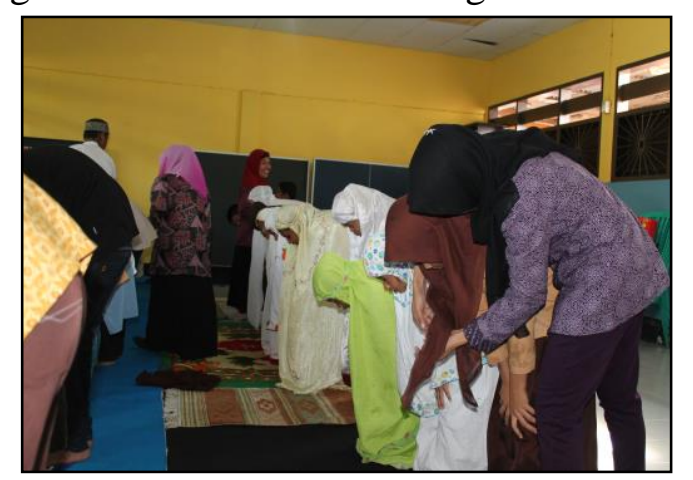

Figure 3. Teaching praying

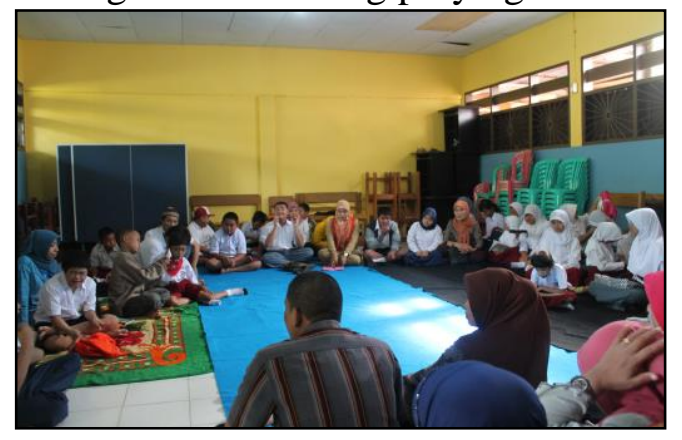

Figure 4. Group learning 


\subsection{Learning Method}

Learning strategies especially Islamic Educators taught to mentally disabled students are individual. And don't always use lecture techniques and don't rely on one method. But it also uses several methods, such as the diachronic method, the awareness method, etc. according to the material being taught. This is similarly expressed by Islamic Religious Education Teachers on mentally disabled students as follows:

The method I use in learning Islamic Religious Educationmust be in accordance with the material I teach. For example material good deeds (morals mahmuda) and bad (morals mazmumah), it means that the method I use is awareness to students that arrogant is bad then it must be avoided. The introduction of these norms includes good and bad deeds so this includes methods that are empirical, can also be problem solving. ${ }^{21}$

After many researchers ask questions with Islamic Religious Education teachers, then they teach, and researchers are allowed to observe activities in learning. The following are the results of the researchers' observations:

Before learning as usual the teacher invites to pray. After that, the teacher

\footnotetext{
${ }^{21}$ Hasil wawancara dengan Guru PAI, pada tanggal 7 Mei 2015 hari kamis pukul 07.40-08.00 WIB.
}

writes some examples of good and bad deeds such as honest, polite, lying, and so on. Then he explained while lecturing and doing it repeatedly, the students were told to classify and do it in a note book. ${ }^{22}$

Based on the data source explanation above it is known that the learning strategies used by Islamic Religious Education teachers is a variety of methods and techniques. When researchers are invited by the Principal to enter room after room to see the teaching and learning activities of the teachers. Here are the results of his observations:

The learning methods and techniques in mentally retarded children are actually almost the same as learning in general. However, the method often used is diachronic or understanding of the material regarding prayer, ablution, good acts, bad deeds, and other worship, and awareness of students to want to do it. The technique can be lectures, questions and answers, drill to continue to practice and practice. Then the important thing is students are also given a compliment.

In addition to observing and interviewing the material on good and bad deeds, the researcher observes learning activities that discuss prayer, as revealed in the following interview:

When entering the classroom as usual the teacher invites students to pray and read the Surah Al Fatihah, the teacher reads while the students

\footnotetext{
${ }^{22}$ Hasil wawancara dengan Guru PAI, pada tanggal 7 Mei 2015 hari kamis pukul 07.40-08.00 WIB
} 
imitate. Then continued learning activities about the prayer movement. Then the teacher writes it on the blackboard about the prayer movements, and tells students to write for those who are able while others still use broken points to be bolded.

In teaching prayer materials the researchers observed Islamic Religious Education teachers who were practicing the prayer movements while explaining them, the students were enthusiastic in following them. Then the Islamic Religious Education teachers justify their movements one by one. After the activity, the Islamic Religious Education teacher invites students to sing their favorite song.

This is similar to what is revealed. Who said that: "In the learning of the prayer movement the method I used was understanding, and awareness. While lecturing questions and answers. Then I give an example, students imitate it. "

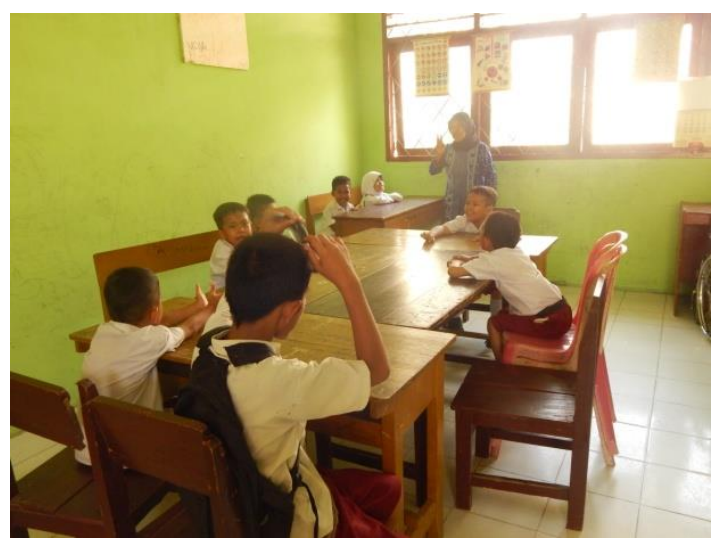

Figure 5. A teacher is giving an example

Other learning activities outside the classroom which are carried out every week in rotation are the practice of ironing, cleaning the glass, washing clothes, washing dishes, sweeping and so on carried out once a week. The goal is to train students to live clean, neat, skilled, and independent.

\section{Conclusion}

This study concludes that the method of learning Islamic religious education in special schools with intellectual disability in ABCD Muhammadiyah is to use examples through direct demonstration to students. In the learning process the teacher uses a more friendly humanistic approach so that students are eager to follow the learning process.

Every day the teachers give various topics of Islamic religious education learning starting in the morning until after hours of study through various demonstration activities. Besides that learning is also done through demonstrations that are carried out together and repeatedly so that students easily practice it.

\section{References}

Ahmadi,Abudan

JokoTriPrastya.StrategiBelajarMeng ajar untuk Fakultas Tarbiyah Komponen MKDK. Bandung:CVPustakaSetia,2005.

Alimin, Zaenal. "Model Pembelajaran Berbasis Konseling pada Anak Tunagrahita' "http://file.upi.edu/Direk tori/pdf (diakses 05 april 2015).

Alimin, Zaenal. "Sejarah Perkembangan Pendidikan Luar Biasa, Bandung : Makalah UPI-PLB, 2004. 
Ali, Muhammad.Guru dalam Proses Belajar Mengajar. Cet. 3; Bandung: Sinar Baru, 2010.

al-Jamaly, Fadlil. Filsafsat Pendidikan dalam al-Quran. Surabaya; Bina Ilmu: 1986.

Al-Maraghi, Ahmad

AlMusthafa.Terjemahan Tafsir AlMaraghi, Juz IV, Terj. Bahrun Abu Bakar. Semarang: Toha Putra, 1993.

al-Toumy al-Syaebany,

Omar Muhammad.Falsafah Pendidikan Islam.terj. Hasan Langgulung. Jakarta; Bulan Bintang: 1979.

Amien, Indrawati. "Strategi Pembelajaran Pendidikan Agama Islam dalam Pembinaan Mental Siswa di SLB Negeri Pembina Tingkat Nasional Malang” http/:uin-malang.ac.id/(diakses 05 April 2015).

Amin, Muhammad.Ortopedagogik Anak Tunagrahita. Jakarta; Proyek Pembinaan dan Peningkatan Mutu Tenaga Kependidikan, 1996.

Anshori, Muchafid.Pendidikan Agama Islam Adaptif untuk Anak Berkebutuhan Khusus. Cet. I; Jakarta: Pustikom, 2014

Arifin, Muzayyin.Kapita Selekta Pendidikan Islam. Jakarta: Bumi Aksara, 2003.

Arikunto, Suharsimi. Prosedur Penelitian Suatu Pendekatan Praktek. Jakarta: Binallmu, 2006.

A. Suhertian, Piet dan Alaida Suhertian. Supervisi Pendidikan dalam Rangka Inservice Education. Cet. Ke-1. Jakarta: Rineka Cipta, 1990.

Bahri Djamarah, Syaiful.Guru dan Anak Didik dalam Interaksi Edukatif. Jakarta: Rineka Cipta, 2000.

Bungin, Burhan. Metodologi Penelitian Kualitatif. Jakarta: Rajagrafindo, 2004.

Darajat, Zakiah dkk.Metodologi Pengajaran Agama Islam. Jakarta, 2001.

Departemen Agama RI, Al-Qur'an dan Terjemahnya. Semarang: Menara Kudus, 2006.
Departemen Pendidikan dan Kebudayaan. Kamus Besar Bahasa Indonesia. Cet. Ke 2; Jakarta: Balai Pustaka, 1989.

D. Marimba, Ahmad.Pengantar Filsafat Pendidikan Islam.Bandung; $\mathrm{Al}$ Ma'arif, 1989.

Efendi,

M. PengantarPsikopedagogikAnakBerke lainan. Jakarta: PTBumi Aksara, 2006.

Fathurrohman,Pupuh dan M.SobrySutikno.StrategiBelajarMen gajarmelaluiPenanamanKonsepUmu mdanIslami.

Bandung:RafikaAditama,2007.

Hadi, Sutrisno.Metodologi Research Jilid II. Yogyakarta: Andi Offset, 1989.

Hamalik, Oemar. Belajar dan KesulitanKesulitan Belajar. Edisi ke-3; Bandung: Tarsito, 1990.

http://www.psp.kemdiknas.go.id/uploads/Sta tistik\%20Pendidikan/0607/index slb

J.Moleong, _0607.pdf. (Akses, 8 Agustus 2015).

Lexy.MetodologiPenelitianKualitatif. Bandung:PT.Remaja

Rosdakarya,2013.

Khodik, Muhammad. "Strategi Pembelajaran Pendidikan Agama Islam Bagi Peserta Didik SMPLB Tunarungu di SLB Yapenas Condong Catur Depok Sleman Yogyakarta"http://library.uinsuka.ac. id/ (diakses 24 Maret 2015).

M. Amirin,Tatang. Menyusun Rencana Penelitian. Jakarta: RajawaliPers, 1990.

M Echols, Jhon dan Hasan Shadily, Kamus Bahasa Inggris - Indonesia. Jakarta : Gramedia, 2000.

Nawawi, Hadari.Organisasi Sekolah dan Pengelolaan Kelas. Jakarta; Haji Masagung, 1989.

Nizar, Samsul. Filsafat Pendidikan Islam, Pendekatan Teoritis dan Praktis. Jakarta: Ciputat Press, 2002. 
Noer Ali, Henry.Ilmu Pendidikan Islam, Cet. Ke-42. Jakarta : Logos Wacana Ilmu 1998.

Poerwadarmita, W.J.S. Kamus Besar Bahasa Indonesia. edisi ke-5; Jakarta : Balai Pustaka, 2013.

Purwanto, Ngalim.Ilmu Pendidikan Teoritis dan Praktis. Bandung: Remaja Rosda karya, 1994.

Rochanah, Tuti.Problematika Proses Pembelajaran PAI pada Siswa Tunarungu SDLB-B di SLB Marsudi Putra I Bantul Jogjakartahttp://library.uinsuka.ac.i d/, (diakses 24 Maret 2015).

Salim, Moh. Haitama dan Syamsul Kurniawan, Studi Ilmu Pendidikan Islam. Jogjakarta; Ar-Ruzz Media, 2012.

Shihab, M. Quraish.Tafsir Al-Misbah, Pesan, Kesan dan Keserasian Al-Quran. Jakarta: Lentera Ilahi, 2009.
Somantri,Sutjihati. Psikologi AnakLuar Biasa. Bandung: RefikaAditama, 2006.

Suparno, Paul.Guru Demokrasi di Era Reformasi. Jakarta: Grasindo, 2004.

Undang-Undang Republik Indonesia Nomor 20 Tahun 2003, Sistem Pendidikan Nasional.usu.ac.id/public/content/file s/sisdiknas.pdf (Akses : Jumat, 17 April 2015).

Usman, Basyiruddin.Strategi Belajar Mengajar dan Media Pendidikan. Jakarta: Quatum Press, 2002.

Undang-Udang Sistem Pendidikan Nasional 2003. Jakarta: Sinar Grafika, 2003.

W. Munawwir, Ahmad. Kamus Arab Indonesia Al Munawwir. Pustaka Progressif : 2002.

Yusuf, A. Muri. Pengantar Ilmu Pendidikan Sistematis. Jakarta: Ghalia Indonesia, 1986. 